\title{
TWO GERMAN-JEWISH RESCUE PROGRAMMES LAUNCHED IN GREAT BRITAIN, 1933-1939
}

\begin{abstract}
Between 1933 and 1939 many British organisations, as well as individuals, who witnessed the rise of Nazi Germany, the implementation of anti-Jewish laws, and growing anti-Semitism, decided to take action. There were numerous attempts aimed at supporting Jews living in the Third Reich, either by providing them with money or by helping them emigrate. This article describes two largest such programmes, i.e. the Kindertransports, and an unnamed action focused on intellectuals, scientists, and artists. The article first discusses the character of both, and then proceeds to explore the question of the character of the migrations presented, as well as the differences between migration and refuge seeking. It concludes with the issue of post-war mobility of the participants of both programmes.

Key words: Jews, Germany, Great Britain, migrants, migrations, forced migrations, forced displacement, voluntary migrations, refuge, Kindertransports, intellectuals, Holocaust, internment.
\end{abstract}

\section{INTRODUCTION: THE HISTORY OF JEWS IN GREAT BRITAIN AS A BACKGROUND FOR 20TH CENTURY BRITISH-JEWISH RELATIONS}

After the creation of the Third Reich, as the political situation of Jews deteriorated, many became more interested in the possibility of emigration. This option, however tempting, was inaccessible to many due to high costs of travel itself, but also because of the ongoing implementation of legislative changes including new limits on the value of the belongings one could carry out of the state. After

\footnotetext{
* Anna M. ROSNER, The Emanuel Ringelblum Jewish Historical Institute, ul. Tłomackie 3/5, 00-090 Warsaw, Poland; e-mail: arosner@jhi.pl, ORCID: https://orcid.org/0000-0003-0053-6000

(C) by the author, licensee Łódź University - Łódź University Press, Łódź, Poland. This article is an open access article distributed under the terms and conditions of the Creative Commons Attribution license CC-BY-NC-ND 4.0 (https://creativecommons.org/licenses/by-nc-nd/4.0/)
} 
the outburst of migrations before the Great War, numerous countries introduced immigration regulations which had complicated things even more. Some, like the United States, had limits assigned to each country, others requested documents proving clean criminal records, financial means of support for a specified limit of time, or medical certificates proving immigrants to be free of contagious diseases.

Among the European countries promising safety and protection, Great Britain took a specific place as it had very little experience in Jewish presence and coexistence. Jews first came to England following the forces of William the Conqueror in the 11th century. They supported his army with necessary items such as weapons or cloth, together with services like tailoring, shoemaking, and even blacksmithing. After King William's victory they settled in the largest cities of the Isles, and their numbers, as estimated these days, were fairly small. Their presence was stopped in 1290, when King Edward I of England issued his Edict of Expulsion. Jews were ordered to either leave the kingdom or undergo conversion by All Saints' Day ( $1^{\text {st }}$ November) the same year. The vast majority of the Jewish population decided to flee and settle in continental Europe. The few who stayed could not simply make an oath and undergo their baptism; their conversion was a long-lasting and very restrictive process organised and controlled by Domus Conversorum ${ }^{1}$. They also remained under strict control of state officials whose responsibility was to file reports on their devotion, piety, and worship. Their houses were subject to frequent inspections; denunciation by their neighbours, like claims of having seen them cultivating foreign traditions, were enough for them to be arrested and tried (Endelman, 2002, pp. 15-16).

Jews were prohibited from inhabiting England until 1655, though it remains clear that they visited the Isles, and in some cases even settled there. Lord Protector Oliver Cromwell started a process which resulted in slowly bringing Jews back to England ${ }^{2}$. Until the 19th century the Jewish population (both Ashkenazim and Sephardim) was fairly small. It increased rapidly after the 1881 assassination of Tsar Alexander II, the rise of anti-Jewish sentiment, and pogroms in the Pale of Settlement which followed. It is estimated that the Jewish population in Britain

\footnotetext{
${ }^{1}$ Eng. House of the Converts, the name of an institution and the building it owned in London dedicated to Jews willing to convert to Christianity. All residents were required to pass all their belongings over to the Crown; in the Domus they were regularly granted small sums of money to cover their basic needs. The process of conversion took several years and was supposed to end with a baptism, being given a new name, and financial support covering the expenses of the beginning of a new life. Jews who underwent the processed were called New Christians.

${ }^{2}$ The process started with a request from a couple of London merchants who were to be expelled as Enemies of the State during the Franco-Spanish War (1654-1660), as Spanish subjects. Realising the fate awaiting them in Spain, they admitted to being Jewish, not Spanish, and asked for refuge on the basis of the long-lasting English tradition of granting safety to all people persecuted in their country of origin. Sir Oliver Cromwell responded favourably to their plea. Despite the existing regulations, Cromwell commonly used contacts with Jewish merchants in the Netherlands; he was also a follower of Millennialism and recognised Jews as an important factor in the theory. For more see Endelman, 2002, pp. 15-38.
} 
was close to $300,000^{3}$ on the eve of the Great War (Endelman, 2002, pp. 127130). During it, when British patriotic spirit and reluctance towards aliens rose considerably, many Jewish men and boys joined the ranks of British Troops (both voluntarily and as conscripts), and formerly traditional families frequently underwent assimilation. Since then a vast majority of the British-Jewish community kept religion in the private sphere of life, rarely used Yiddish, and spoke English; they also participated in the political and cultural life of Britain.

As a result of this Anglo-Jewish history, most stereotypes about Jews popular elsewhere were uncommon, or even unknown, in the Isles. The very last pogrom in England occurred before the expulsion of 1290. Jews gained fully equal legal rights to those of non-Jewish origins in the late 19th century. They gained free access to all professions, had the right to vote in elections and to be voted for, they sat in the House of Commons, and held important positions in the state.

Between 1933 and 1939 two large programmes aiming at helping German Jews launched in Great Britain. In both cases the government cooperated with Jewish organisations, and in both cases this cooperation led to a special approach towards Jewish immigrants. That is especially visible when investigating requirements which applied to entering the Isles, which were lowered for Jews.

The first of the programmes focused on intellectuals, scholars, artists, and people whose specific skills or knowledge were considered useful by the authorities. It was never given a name and was based on Winston Churchill's speech in which he said: "Since the Germans have thrown out their best scientists we have made whole benefit of it."

The second is known as the Kindertransports and it was aimed at helping Jewish children under the age of seventeen. It is estimated that around 10,000 of them, mostly originating from large cities, travelled to Great Britain thanks to such organisations as the World Movement for the Care of Children from Germany and the Jewish Board of Refugees.

While the Kindertransports seem reasonably well researched in the United Kingdom, the subject is rarely discussed and analysed in Poland. The migrations of German-Jewish intellectuals and artists, as well as the organisation of the programme itself seems to be rarely investigated by Britain-based scholars, and the subject is nearly never researched in Poland. In both cases it may be debatable whether the people aided by the programmes could be recognised as refugees or as immigrants. The Kindertransports also elude easy classification as voluntary or forced migrations.

\footnotetext{
${ }^{3}$ It is impossible to give precise numbers of Jews living in Great Britain at that time. Many migrants treated London and other large cities as transit points on their transatlantic route. Some had to stay for a shorter or longer time, some settled for good. The censuses conducted every ten years did not show this population movements in sufficient detail, and there are no border records providing accurate information on the matter of the number of immigrants before 1905.

4 'Britain and the Refugee Crisis 1933-1947', Sir Ludwig Guttmann, Accession No. 004596/03, Parkes Institute Archive, Hartley Library.
} 


\section{PROCESS OF CREATION AND THE COURSE OF THE PROGRAMME FOCUSED ON ADULT INTELLECTUALS, ARTISTS, AND SCHOLARS}

After the 1933 elections and the introduction of the first anti-Jewish laws (such as the Third Reich Citizenship Act of September 1935), the topic of a possible migration became more pronounced in the community of assimilated Jews. For many it was clear that the sooner they made the decision, the easier it would be to leave the Reich. The time proved them right as in the early stage of the migrations many could have used passports issued prior to the inclusion of a reference to the Jewishness of their bearers, could have carried more belongings with them, and often needed to fulfil fewer requirements in the destination country.

One of the fortunate emigrants was Hans Krebs, a professor in biochemistry and a Nobel Prize laureate, born to a Jewish family in Hildesheim in 1900. He decided to leave the country as early as in 1933, wishing to settle in Great Britain (he was later employed at the Oxford University). In the 1960s he agreed to participate in a project launched by the Imperial War Museum which aimed at recording as many interviews with Jewish pre-war immigrants who became important figures in science as possible ${ }^{5}$. When asked about the difficulties related to leaving the Reich, he replied:

There were no restrictions, I had of course to have a passport. The restrictions were of a financial kind I couldn't take any money out of Germany. I could take my personal belongings and my books but technically I would only be allowed to take a sum of ten marks which was less than a pound. But by hiding some money in the form of notes I took enough to keep me going for two or three weeks. And the real worry was that at any time that the frontier would be possibly expected to be stopped. But the Nazi machinery was not as efficient as it became later and there was in fact no difficulty in free travelling for anybody. Not anybody who was not yet in a concentration camp. I had not been politically active in any way and therefore I was not on the early lists but students or other people who had been connected with communism in particular had already been arrested and sent to concentration camps. So I had no difficulties in leaving (Accession No. 004498/05, p. 20).

While British research facilities and educational centres were relatively open to researchers from Nazi Germany, they had set some requirements for them themselves. In the first years following the Nazi rise to power a scholar wishing to arrive to one of the British facilities had to prove that it was possible for them to continue their research, and discuss why their work would be of any benefit to the hosting unit. In the second half of the 1930s, it was already required for them to show that in the event of failure to obtain a full-time job, they would be able to support themselves with their private funds.

\footnotetext{
${ }^{5}$ This collection, now held in the Parkes Archive at the University of Southampton, is the most complex primary source for research on this migration movement.
} 
The second of the restrictions mentioned might have seemed fair to the authorities of the facilities or research units, however, it was for aspiring immigrants nearly impossible to meet due to Nazi regulations. This issue was shortly answered by the employees of the universities and other hosting scholar units.

Some universities offered special scholarships, but the application process was challenging. The applicants were expected to prove they faced danger from the Nazi regime and needed letters of recommendation from their tutors and co-workers. Any contacts made earlier, for example during conferences, proved extremely valuable at this point as applicants were expected to name scholars who would support their application and testify about their professionalism and the importance of their research.

As early as 1933, the Academic Assistance Council was established at the Westminster College in Cambridge. It was to cooperate with other similar bodies in other countries while gathering money to support displaced university teachers and researchers. In its appeal for funds the Council stated that "all who are concerned for academic freedom and the security of learning" could support the cause. The Council was apolitical and its goal was to "relieve suffering, prevent waste of valuable talents, and defend learning." Sir William Beveridge and Prof. C. S. Gibson were honorary secretaries of the Council ("Academic Assistance Council', p. 793). In 1936 the Academic Assistance Council transformed into the Society for the Protection of Science and Learning and after it merged with the Notgemeinschaft Deutscher Wissenschaftler im Ausland it was renamed to the Emergency Association of German Scientists in Foreign Countries. Throughout its existence the Council had just one goal: to support all scholars born in German territories who had suffered from the recently introduced racially-based laws, had lost their jobs or sought new employment outside of Nazi-ruled locations. Throughout its operations the Council was financially supported and utilised private donations only. The gathered funds were later offered to arriving scholars if they were required to show they could support themselves. The loans were non-returnable but it was obvious to the beneficiaries to, at some point, donate money in return (Accession No. 004596/03, p. 78). The financial aid the immigrants could expect both during their travel and after the arrival was absolutely crucial. A vast majority of them had already lost their jobs and lived on their savings for extensive periods of time. Being settled in Great Britain was for them the beginning of a new life, but it was by no means the end of the struggle. Though some researchers had positions waiting for them, especially those who arrived at the early stage of the programme as well as the most prominent ones, many did not and had to apply for a job. Understandably they wished to work in the field they knew from before. The positions, even if available, had high requirements set by future employers. Their ability to work, often write and teach in English, was the most important and troublesome. 
The Emergency Association of German Scientists in Foreign Countries organised competitions to select the most promising and most experienced scientists needing help. The winners of the competitions were awarded grants and scholarships, as well as long-term contracts at British universities. Those who were not fortunate enough to gain one were helped in a different way. The Association made various attempts to distribute information on such people, as well as on their abilities, to units not cooperating with the Association. It was clear that if an applicant specialised in a specific field of science, certain facilities could have been interested in working with them. Due to a limited number of positions that could be offered by universities (scientists with modest or no communication skills in English were unlikely to receive any posts) in the second half of the 1930s, the Association opened a new programme. Using the same source of funding, it invited researchers and intellectuals to 'lecture tours' throughout selected academic centres in Great Britain and the United States (Accession No. 004596/03, p. 78). This was a unique chance for the scholars to present their skills, knowledge, and achievements in front of many powerful academics, who could decide to offer them a position.

Professor Ludwig Guttmann, a neurologist and the initiator of the first Paralympic Games, left for Oxford in 1939. In his interview he spoke on emigration and claimed it would not have happened if not for the support of his former superior who had gained an extraordinary reputation in Great Britain:

And my teacher, Professor Foester, was very well thought of. In fact in 1937 or, 38 the whole British Neurosurgical Society paid a visit to him. And he is one of the very few foreigners who has been made an honorary of the Medical Association of Great Britain (Accession No. 004596/03, p. 25).

Professor Carsten, who became a lecturer at Wadham College, recalled how through 'lecture tours' he managed to visit Great Britain. He had received a scholarship to extend his stay by dint of semi-private conversations during coffee breaks between the lectures:

(...) And I only got permission to stay for a very limited period. But when I got the scholarship to Oxford this was then extended. (...) I went around the colleges in Oxford and Cambridge trying to find out what I could apply for and there were only a small number which were open to people without a British university degree and for those I applied and I finally got one of them (Accession No. 004596/03, p. 25).

The official goal of 'lecture tours' was to spread knowledge and exchange research techniques among the participants. In reality many of the people participating in this programme got the chance to enter the United States - not as refugees, but as academic guests, which made a huge difference. Owing to the favourable treatment by the British government they travelled using not German 
passports, but temporary British travel documents. They gained the opportunity to establish contacts, find interesting employment opportunities, and apply for a residence permit in America.

The Society for the Protection of Science and Learning operated from 1933 to 1945 and arranged placements for 2,541 people. According to the fifth annual report published by the association in 1946, there were 601 scientists participating in the programme in Great Britain. The rest found employment in their professions elsewhere, mainly in the United States. About $40 \%$ of those remaining on the British Isles worked at universities and research facilities, and 36\% in industry and government-related institutions. Among those, most of the arrivals from the Netherlands, France, and Scandinavia returned to their home countries as soon as the war was over. Those coming from Poland and Czechoslovakia were covered by another special programme, the purpose of which was to protect them against expulsion to their country of origin and to allow them to remain permanently on the territory of Great Britain. In 1946, similar programmes were planned to be launched for Jews from Germany and Austria. From the 1930s until the end of the 1950s, the Jewish population from the Rome-Berlin-Tokyo Axis countries was subject to surveillance by the police and the MI5 counter-intelligence agency. Those who showed loyalty to their new homeland could undergo the process of naturalisation. Afterwards, if they had wished to, they could be allowed to join the British army or work in enterprises cooperating with the military or government institutions. If after the war they wished to return to continental Europe, they were offered the option of settling in the western occupation zone (Rutherford, 1936, p. 607).

It seems important to mention that some of the refugees never gained the trust of the British authorities. That applied especially to people deeply associated with the traditions and culture of the country of their origin, reluctant to learn English, not looking for a permanent job in Great Britain, or openly admitting their willingness to return to their home countries after the end of the war. They, as well as the British Nazi sympathisers (including Oswald Mosley, the members of the British Union of Fascists (BUF) founded by Mosley, and the members of the Black Shirt movement (Endelman, 2002, pp. 202-203)), were under constant surveillance by the MI5. In accordance with British traditions, citizens of countries against which Great Britain conducted hostile operations were treated as enemies of the state. During the Second World War, immigrants and refugees from the Rome-Berlin-Tokyo Axis countries - both political refugees and others - were referred to as 'the enemy aliens'. In the event of prolonged doubts regarding political beliefs, sympathies, or even a suspicion of espionage, the suspects were arrested and interrogated on the basis of Paragraph 18B of the Emergency Power Acts, abbreviated as Defence Regulation 18B (Goldman, 1973, pp. 120-136). This law was a clear continuation of First World War inner-state legislation, when it was agreed to limit the freedom of citizens and 
immigrants only if this could contribute to the improvement of internal security. Research shows that the police and the MI5 employees were exempt from the requirement to present any charges to a detained person. The internment was for an indefinite period of time, but according to Defence Regulation 18B it should end with the resolution of a political crisis or the conclusion of peace if war was already declared. The exact number of the interned and their related records have not been fully available since 1958 when the British parliament voted to keep this data classified for one hundred years.

A person arrested under the Defence Regulation 18B law first underwent interrogations at police stations. Usually, after a few days, the arrestees were transferred to a camp or prison. Those facilities were usually located on small, isolated islands or in the countryside. Later, when the number of the interned grew, old and decommissioned prisons, or even factory halls, were adapted to hold them. One of the most famous camps for German Jews was located on the Isle of Man in an abandoned factory and the surrounding territory. In 1940 , the number of internees in this camp alone reached 14,000, including people in a separate space for men and women (children stayed with the women $)^{6}$. It is estimated that this number accounted for about a third of all prisoners of Jewish origin.

Earlier, in September 1939, there were approximately 70,000 enemy aliens in Britain $^{7}$, of which approximately 65,000 were refugees who had not lived in the country for more than five years; approximately 50,000 of them spoke openly about their Jewish origins (Kapp and Mynatt, 1997, p. 75).

In 1939 special courts were established with one aim only - to decide the further fate of the interned. During the first year of their existence they ruled in over 60,000 cases, releasing the vast majority of the defendants and granting them the status of 'friendly aliens'. At the same time the British public opinion was for the first time faced with the reports on the conditions in the camps. In some cases they did not even follow the norms described in the Geneva Convention (Goldman, 1973, pp. 120-136).

Professor Carsten, arrested and interned in the Wharf Mill camp, surrounded with barbed wire and guarded by the British military, recalled:

Well, it was a disused cotton factory with bits of machinery still lying about or falling down from the ceilings and in a derelict state. And the camp commandant called all the prisoners together on and off and gave them lectures on British virtues and politics which nobody wanted to hear and otherwise collected razor blades and similar items from the suitcases of the internees. (...) And also confiscated all books because they might contain codes for communicating with Germany (Accession No. 004596/03, p. 19).

\footnotetext{
${ }^{6} \mathrm{http}$ ://timewitnesses.org/english/IsleOfMan.html [accessed on: 28.01.2021].

${ }^{7}$ That included immigrants from all the enemy countries including Germans, Austrians, and Italians, regardless of their religion or declared ethnic backgrounds.
} 
It was common for the refugees to speak of the hardships and distress they had to face while in Great Britain, and about the British citizens recognising them not as Jews seeking refuge but as representatives of the Third Reich.

Professor Carsten recalled the difficulties related to the refugee status. In addition to his identification as an enemy alien, there were extra restrictions imposed on him and other refugees. If they broke them they could be arrested, interned or they could face espionage charges.

...there was a curfew, one had to be home if I remember rightly by $10 \mathrm{pm}$ and was not allowed at night and wasn't allowed change one's residence without a police permit and had to register immediately with the police wherever one went to. (...) And there were protected areas into which one was not allowed to go as an enemy alien; along the coast et cetera (Accession No. 004596/03, p. 17).

Adult refugees faces hostilities coming mostly from ordinary British people, among which Germanophobia, heavily present during the First World War, rose once again. These hostilities included difficulties in finding accommodations, being mistreated in shops, and refusal of service in places such as the barbers, the tailors, the shoemakers, and even pubs, the foci of local community life. They were often given signs of being unwelcome at private meetings of various kinds. Similar instances occurred also at universities and research facilities hosting the refugees, but they were not as common as in the outside world. The identification of non-British neighbours or co-workers in the vast majority of cases was based on their foreign, German-sounding accents and poor English language skills. The anti-alien sentiment weas somewhat fuelled by some of the media, both radio and the press, who before Mosley's arrest frequently spread the ideology he promoted.

Sir Hans Krebs spoke about it:

Well in Cambridge, and later in Sheffield and Oxford, I personally found always very much friendliness. But there were of course expressions in the press, especially on the part of Sir Oswald Mosley and his fascist party, of anti-foreigner feelings (Accession No. 004596/03, p. 17).

Even though Great Britain had not welcomed the participants of this programme warmly, it was the possibility of migration itself that mattered the most for them. Many testimonies left by them show one more struggle they had to face: helping their families out of Nazi Germany. In the early days the option for entire families to travel together was rather common, but later the organisers asked the scientists to arrive on their own; they themselves had to help their relatives leave their countries of origin.

After the outbreak of the Second World War many of the scholars who could in any way add to the general effort, did so. Professor Ludwig Guttmann, for example, worked with wounded soldiers and planned their rehabilitation. His innovative methods are still being used in post-trauma medicine. 


\section{THE KINDERTRANSPORTS: THE PROCESS OF CREATION AND ITS COURSE}

Less than a week after the events of Kristallnacht, British organisations aiming at helping German Jews understood the need of a rapid extension of their activities to cover more than just intellectuals or artists. It was then decided that the primary focus should be on children - innocent, defenceless, exposed to violence no less than adults, and often unaware even of the reasons for the persecution. It remains the subject of a dispute who the originator of the project was. It is, however, obvious that the Children Refugee Movement and Bloomsbury House were involved at the early stage planning, similarly to several other organisations, and even British Quakers.

Jewish communities and associations sent a delegation consisting of their most influential members to Neville Chamberlain, British Prime Minister, to discuss the matter. One of the postulates presented was the consent to the creation of a special programme to help Jewish children from areas under the Nazi regime. According to its assumptions, the children were to arrive without their parents or any guardians, and return to them as soon as it would be possible - with the end of the Nazi rule or the end of the anti-Jewish incidents. That period of time was estimated to be a couple of weeks.

During the meeting of the British Cabinet, a decision was made to temporarily agree to organise transports for children and adolescents aged between three months and seventeen years. The decision was largely influenced by the fact that similar programmes were discussed in the United States during the same period. British organisers of the transports were required to ensure that adequate funding, i.e. $£ 50$, was secured for every child. The money was to be later used to cover the expenses of their return trips 8 .

The children were expected to arrive alone and the lack of the guardians was justified by the restrictive immigrant British law. There was also a popular belief that even though the Jewish population in Germany was being persecuted, the scale of such events would not suddenly increase and the situation of Jews in Nazi-ruled lands would not worsen. In addition, there were fears of a mass migration of a population who would be forced to use social welfare and financial assistance in the first stage after their arrival, only to flood the labour market later; the British economy could not afford such an expense. Concerns about lowering labour standards and significant reductions in wages in such cases were common and strong among nearly all classes of the British society. The authorities believed that the arrival of children, even in large numbers, would not be associated with similar threats, especially since they were expected to only spend a short period of time on the British Isles.

\footnotetext{
${ }^{8}$ http://www.kindertransport.org/history.htm [accessed on: 28.01.2021].
} 
The arrival of unaccompanied children was also perceived as being safer by the MI5 officials who continuously feared Nazi spies among adult immigrants. This, however, did not mean that the Kindertransport children were not watched by the counter-intelligence. There were rare but known cases of surveillance being undertaken in case of older children, as well as cases of internment.

The Kindertransports ${ }^{9}$ started in the late 1938, and the first group, consisting of 200 children, arrived at Harwich Harbor on 2 December 1938. The very last group left Germany on 1 September 1939. Before the outbreak of the Second World War, approximately 10,000 children, mainly from Germany, Austria, Czechoslovakia, and even the Free City of Gdańsk ${ }^{10}$, arrived on the British Isles. The main organisers of this initiative on the German side were synagogues, local Jewish communities, and related organisations. Information on the possibility of having a child send to Great Britain was distributed mainly in synagogues ${ }^{11}$; lists of applicants and information about the pre-requisites were also available there.

There is a vast number of publications containing the memories of Kindertransport children after they became adults. They frequently recalled the moment when the information about the possibility of departure first reached their families. Most often it was associated with a service in synagogue or a meeting of the members of the local community; in several cases the news spread among relatives and friends. Orphanages - both for Jewish and Christian children - need to be considered as a separate case. Such facilities, seen as institutions giving shelter to already-traumatised children, were granted a higher priority, and so it was easier for such children to be enrolled. Also in the late 1930s orphanages in the Third Reich faced a considerable increase in the numbers of Jewish children requiring their help, mostly due to the poor financial situation of their families (worsening with the implementation of laws banning Jews from certain professions), but also due to the internment of some of their parents. Sending orphanage pupils away was a convenient solution, offering not only a chance to ensure the safety of those children, but also allowing the facilities themselves to reduce the already high numbers of children in their care.

On the British side, these transports were mainly organised by charitable organisations such as the World Movement for the Care of Children from Germany or The British Committee for the Jews of Germany ${ }^{12}$, supported by numerous volunteers and donors. The Jewish Board of Refugees and the Jewish Refugee Committees ${ }^{13}$ also played a significant role as they were responsible for commu-

\footnotetext{
${ }^{9}$ Also known in British historiography as the Refugee Children Movement.

${ }^{10} \mathrm{http}: / / \mathrm{www}$. kindertransport.org/history.htm [accessed on: 28.01.2021].

${ }^{11}$ Not all synagogues or communities participated in the programme. The limitation was imposed by the British side.

${ }^{12} \mathrm{https}: / /$ encyclopedia.ushmm.org/content/en/article/kindertransport-1938-40 [accessed on: 28.01.2021]

${ }^{13}$ https://www.worldjewishrelief.org/about-us/kindertransport [accessed on: 28.01.2021]
} 
nication with the government and ministries whose approval was necessary when placing children in boarding schools, orphanages, or with foster families. Their staffs were also responsible for checking in with the families hosting the children, and in the post-war period for finding those children whose parents had survived the Holocaust and managed to make contact.

Since the age range of the rescued children varied from toddlers to near-adults, their recollections contained different level of detail. The older the children were, the more of what was happening around them they understood and, no less importantly, the more of the background they considered worth recording in their letters or memoirs. The younger ones were less aware and their documents have little or no information on the departure or farewells.

Lee Edwards, five years old on the day of the departure from Frankfurt, recalled:

It's March 1939 and a whole group of children are huddled together under the watchful eyes of the Nazi police. The children are wearing numbered labels around their necks - no names, just numbers - and their mothers and fathers are bidding them a tearful goodbye. We are off to England, without our parents, to a strange land, strange people who offered to take us into their homes; thus saving our very lives. But we don't realize this on this grey March morning, we are leaving our loved ones behind; we don't know it, but most of us will never see our parents again. My mother is wiping her eyes with a little dainty handkerchief, and I help her smooth the wool blanket on top of the suitcase after the police have searched it and allowed it to be closed (Leverton and Lowensohn, 1990, p. 79).

While many documents written by these children are available to researchers these days, there are almost no testimonies of their parents, the vast majority of whom had perished in the Holocaust. Still, the difficulty of deciding to send a child away, into the unknown, cannot be questioned, as much as the desperation behind this decision. As mentioned earlier, the organisers of the programme assumed that the children would be reunited with their families in just a few weeks' time, and the Kindertransports were planned to be a moment of relief, a brief time spent in a safer place. Although the parents, as well as the children, had no reason to assume their farewells were final, some memoirs prove it otherwise.

There are few known cases of children who travelled to Great Britain with the Kindertransport and were taken home by their relatives on arriva $1^{14}$. Most of the children were either picked up straight from the train station by families willing to accommodate them, or sent to orphanages or boarding schools. The organisers of the transports tried to make the stay of the distressed children more pleasurable and for as long as it was possible encouraged British families to host the children in their homes. The response of the British society was strong and many families of different social backgrounds and status offered shelter. Collections of letters written by the children, published years after the war had

\footnotetext{
${ }^{14}$ One such case was Arno Penzias, who joined the Kindertransport in Gdańsk. His family, previously deported from the Third Reich, hosted him and his brother (Leverton and Lowensohn, 1990, p. 240).
} 
ended, show that most such families granted a second home filled with love and a great atmosphere. Some abused the situation and instead of taking care of the adolescents they had treated them as domestic servants or unpaid labour force. It was the responsibility of the organisations behind the Kindertransports to check on the welfare of the children, however, due to the insufficient numbers of employees and the number of children being higher than expected, it quickly proved an impossible task.

During the early stage of their stay most of the children could exchange letters with their parents. News from the family and home helped the youngest cope with traumatic experiences, while letters written by the children proved to the parents they had made the right decision. Irene Liron, who arrived in London in May 1939, recalled:

Eventually I was a bit of a tomboy, and after few days of settling down in my new home, started climbing trees. My foster mother wrote of this to my parents, and straight away I got an urgent letter from my mother. 'You mustn't climb trees', she wrote, 'You must not add worries to your new family. You must not be wild. You must be obedient. You must be quiet. You must be grateful that they took you. You must be very good. You must do all you are asked, and even read their wishes from their lips before they are said'.

Actually all her letters were somewhat similar. Always reminding me to be good and grateful, and always complaining that I wrote so little in my letters to them. But looking back now, I don't see how a ten year old child could be expected to write long letters every week, but I do understand my mother's worries about my possible bad behaviour (and the possibility of being send back). I should hate to be in her situation where she had to send her youngest daughter to unknown people in a foreign country (Leverton and Lowensohn, 1990, p. 197).

The children's situation became more complicated with the outbreak of the war. Many caregivers who agreed to take a child in for a short time began to fear that the war might last much longer than it was commonly believed and they would be left with an additional burden for years to come. Older children, especially those staying in orphanages, were often considered fit for work. This happened with Gideon Behrendt, a boy born in Berlin, whose father was arrested and deported to the Buchenwald camp in June 1938. Gideon was sent to an orphanage and, owing to the efforts of its employees, came to Great Britain in December. He was then sent to Leeds, where he lived in a centre for Jewish orphans in Stainbeck Lane. Initially, the children were looked after by a special committee composed of representatives of the local Jewish community who covered the costs of the essential needs, and expected the children to learn English well enough to start attending school.

All too soon the war started. Priorities changed and instead of learning how to be gentleman we went to work in the factories. Model, our father figure, was taken away from us and replaced by $\mathrm{Mr}$ Meier and, shortly after, by Mr S and his wife who made the once so happy hostel in Stainbeck Lane into a place that can best be compared to the orphanage described by Dickens in Oliver Twist (Leverton and Lowensohn, 1990, p. 31). 
With the outbreak of the war it became clear that the older of the Kindertransport children no longer perceived Germany as their homeland. They felt connected with their biological families, with places where they grew up, with their communities, but in the autumn of 1939 they oppossed the state which had persecuted their loved ones and themselves. Many memoirs bear information on their willingness and attempts to join the British army or enrol to help essential civil institutions.

Albert Eisner (Edwards, after he accepted the surname of his adoptive family), born in Vienna and settled in Manchester, wrote:

When I reached military age I fought my way into the British Army, not the usual Pioneer Corps background, but straight into the Royal North Lancashire Infantry Regiment.

Eventually I landed in Normandy on D+6 and joined $2^{\text {nd }}$ Army HQ Intelligence Section.

The war went on, we broke out of Normandy and eventually reached and liberated Belgium

(...)

Our postal address ended with ,BLA'. This stood for British Liberation Army.

On that day, more than any other day, I felt that this is indeed what we were (Leverton and Lowensohn, 1990, p. 81).

Many tried to enlist, but for various reasons only some were accepted into the army. The refusal was usually based on insufficient language skills or a lack of physical fitness. Some who were considered unfit to fight were assigned to work in institutions related to intelligence or in civil support. Among the memoirs there are several written by translators who used their German language skills to decipher messages and translate intercepted orders. Others, especially those too weak or too young to enlist, sought opportunities to work in train stations, military hospitals, or factories sewing uniforms. Some volunteered to units essential to city safety where their duty was to guide people to shelters during air raids or to remove debris. Such positions usually paid little or nothing at all, but it was the act itself, the feeling of being able to help at the time of war, that mattered to the Kindertransport children.

\section{MIGRATION OR REFUGE? FINDING A PLACE TO SETTLE}

Ernest Georg Ravenstein, one of the first to ever have focused on the subject and described the characteristics of migrations, identified two basic kinds of massive human population movements in terms of decision-making: forced and voluntary (Lee, 1972, pp. 9-28).

All migrations, as Ravenstein has argued, require push and pull factors, where the former are responsible for the reason and the impulse to leave a place of residence, and the latter for choosing the destination. When focusing on the German-Jewish migrations the push factors are clear, yet the pull factors differ. 
In the case of the migration of the intellectuals, scholars, and researchers the pull factors were, e.g. safety, but also the employment and work possibilities, and in some cases knowledge of the English language. The familiarity of the local research society was not a key factor, but played a role as well. One could wonder to what extent the migration of the intellectuals was voluntary, yet what is certain is that these people made their choice themselves. The push factors were of an extreme kind, and it was not the economy, nor the possibility of further work that played the biggest role for them. Some interviews with the intellectuals contain clear statements on how the persecutions and growing anti-Semitism in Nazi Germany made them understand that their lives would be in danger should they remain. Looking from today's perspective, we know that the situation of Jews in the early years of the migration was not as bad as in the last period when leaving Nazi Germany was still possible. However, we need to remember that back in the 1930s each instance of the deterioration of the conditions was a surprise and a majority of people believed it would not get worse over time.

When discussing the Kindertransports, the pull factors are different and only the matter of safety could be considered. In fact this and the origin of the organisations conducting the programme are the only existing factors. Ravenstein wrote about forced migrations assuming population movements not in any way chosen by the migrants but imposed onto them. Such subjects are pushed away from their homeland or deported, deprived of free will and the ability to choose. That can be definitely said about the Kindertransport children who (apart from only a few known cases) had no influence over their fates. It was their parents or caretakers who made the decision, and the organisers allocated them to a family or in a facility without asking them whether they would prefer one over the other. There was also no possibility of changing one's mind or returning if the child felt homesick.

It seems that by looking at the push factors for both of the programmes described it can be easily agreed that they fulfilled the definition of refugee programmes, and the Jewish-German immigrants to Great Britain were in fact not immigrants but refugees. Accordingly to the United Nations Refugee Agency, a refugee is "a person who is outside his or her country of nationality or habitual residence; has a well-founded fear of being persecuted because of his or her race, religion, nationality, membership of a particular social group or political opinion; and is unable or unwilling to avail him- or herself of the protection of that country, or to return there, for fear of persecution" 15 . Today's definition was, however, non-existent in the period discussed and, therefore, while we define the movements as seeking refuge, it's also possible to call them migrations.

Apart from that the migrations mentioned in the article fulfilled the requirements of other laws specified by Ravenstein, even if they could be mostly related

\footnotetext{
${ }^{15}$ The 1951 Convention Relating To The Status of Refugees and Its 1967 Protocol, The United Nations Refugee Agency (https://www.unhcr.org/4ec262df9.pdf) [accessed on: 28.01.2021].
} 
to the migration of intellectuals and artists. Clearly few of the laws refer to internal migrations only, and those should not be considered.

What also seems interesting is the fact that the early stage migrations of the adult German Jews, who became subject to the mentioned project, had unintentionally created a migratory network. This phenomena should be understood as a set of connections linking migrants, ex-migrants and non-migrants, both in the country of departure and the destination through exclusive social bonds. Migratory networks provide certain helpful features: they protect migrants from the risks related of the migration; organise the migration process (with such issues as travel document obtainability, travel itself, settling possibilities included, etc.); share information on the benefits and drawbacks related to the a destination; aid in the labour market; and they also create an 'immigrant community'. The last of the mentioned is considerably easier when immigrants share a background and/or professional field.

German-Jewish refugees were faced with one extremely difficult question relevant to their post-migration identity. They were usually assimilated Jews who did not feel a strong connection with Zionist ideology and, therefore, prior to their refuge they would rather call themselves Germans or Austrians than Jews. Yet they had been forced to leave the country in which they were born, grew up, learned, worked, and had close connections to its culture. Then they settled in a place often not of their own choosing - a country which in 1939 found itself at war with their homeland. The laws introduced in the Third Reich made them question whether they could still consider themselves German, while the British authorities identified them as German until naturalisation or adoption. The matter of the lost identity was more than common among adult migrants while it was less of an issue for the children who frequently never even asked themselves this question.

The infants and youngest children adapted to the situation naturally and underwent acculturation unconsciously. Having no contact with other Kindertransport children, they fully switched to English and forgot their previously acquired skills. The loss of contact with their families often resulted in a quick assimilation and acceptance of the British national identity as something natural.

The feeling of belonging proved important in the post-war era when travel to continental Europe became possible again. Most of the Jewish-German refugees did not wish to go back to Germany, and those who did were offered to settle in the western occupation zone. Some decided to move to Palestine (later the state of Israel), and this was mostly motivated by the possibility of finding any remaining relatives or showing their ties to their Jewish roots. Many of the youngest participants of the project stayed in Great Britain until adulthood and later had shown high migrative mobility throughout their lives. When choosing a place of residence, they were rarely guided by any patriotic feelings, instead the decisive factor was pragmatism/acquaintances or adoptive families to whom they managed to become attached, the knowledge of culture, education or finding a satisfactory job. 
Larry Mandon, who changed his place of residence several times, wrote on his identification:

I have lived in England since 1938 although I have travelled extensively throughout the world (Leverton and Lowensohn, 1990, p. 206).

A considerably large number of the Kindertransport children emigrated to the US and Australia. While migration to Israel was mainly driven by the Jewish community and culture, those who travelled across the Atlantic most often did so in search of work, education, or - as they said - to get away from places that connected them with suffering. An equally important factor was political awareness, which was extremely strongly developed in the children included in the Kindertransport programme.

Eddie Nassbaum, born in Hamburg, left England in 1949. He shared the reason for his decision:

In my case, winning a post-graduate Fellowship brought me to the United States in 1949. On returning to the UK I was not happy with the policies of the newly elected Labour Government, and, with my new bride, I decided to settle in New York. We now have two married children and three grandchildren (Leverton and Lowensohn, 1990, p. 235).

While the Kindertransport children showed high mobility, adults were much more likely to stay in Great Britain. In their case naturalisation, necessary to obtain citizenship, was a key factor. Knowing that without a British passport they would risk being interned or even expelled from the Isles, they decided to accept the citizenship of a country to which they did not always feel attached. Attempts to find a job and settle elsewhere in their case would entail the necessity to undergo similar procedures, not to mention adapting to the new place and learning customs and culture from scratch.

Professor Carsten, when answering the question about his children, probably best answered both the question about his cultural identity and about how his children identified themselves:

They understand a lot but when they try to talk German it's not very good

(...)

They have been born in London, they have been to school in London, I think if they think of themselves at all, they would think of themselves as English. I honestly don't know what I am. You know in a way I think of myself as being German but after such a long time and having lived here so long my ties with Germany have naturally became fairly loose - although I go there several times every year to work in archive and go to conferences and meetings or give lectures in Germany (Accession No. 004596/03, p. 35).

The common feature of the authors of the memoirs is the constant questioning of one's place in the world. Some have found it either by returning to their 
birthplaces or by deepening their ties with Jewish culture and religion - sometimes also by moving to Israel. Some did not feel the need to find one place for themselves and moved easily following their jobs or loved ones. Still most of them struggled with the issue of identity throughout their lives.

\section{CONCLUSION}

Both of the programmes described were exceptional on a global scale. The first was unprecedented and although it remains impossible to offer a full list of the people who benefited from it, its significance and influence to the British science and education is unquestionable. Also, apart from Great Britain, no other country organised an action under the government's patronage that would lead to the departure of such a large group of Jewish children from the areas affected by Nazi ideology.

Focusing on their uniqueness one needs to remember that both of these actions had some issues and flaws. In the case of the former one can not only discuss whether more people could have been saved (including scholars denied scholarships or the families of refugees), but also how those who came to Great Britain were perceived by the society. Defence Regulation 18B had been definitely overused, and the possibility of internment without any charges being cited for an unknown period became one of the biggest threats to all refugees and immigrants of German, Austrian, or Italian origin.

In the case of Kindertransports, as mentioned earlier, there was no sufficient oversight over the caregivers. There were cases of abuse and mistreatment both in the institutions and foster families. After the war the families hosting the children whose parents were known to have died or who did not make any contact and were therefore assumed dead could apply for a full adoption. In a vast majority of the cases the process was swift, benefiting both sides as it granted legal approval of the relations developed during the war. There are known cases of adopted Jewish children who were too young to remember their lives before the extraction. The insufficient system of oversight and the fact that such children developed very deep bonds with their caregivers and frequently treated them as their parents had led to a new issue: the denial of information about the child's identity.

However different the organisation and the fulfilment of these migrations have been, there was one thing that remained in common for both adults and the children who sought refuge in Great Britain. It was the feeling of gratitude and understanding that they had survived the Second World War and escaped the biggest threat possible, unimaginable at the time of their departure. 


\section{REFERENCES}

'Academic Assistance Council' (1933), Nature, 131, 793. https://doi.org/10.1038/131793c0

BERGHAHN, M. (1984), German - Jewish Refugees in England - The Ambiguities of Assimilation, London: MacMillan Press. https://doi.org/10.1007/978-1-349-04210-4

Britain and the Refugee Crisis 1933-1947, Imperial War Museum, Department of Sound Records, Parkes Institute Archive, Hartley Library.

ENDELMAN, T. M. (2002), The Jews of Britain 1656 to 2000, Berkeley: University of California Press. https://doi.org/10.1525/california/9780520227194.001.0001

EVERETT, S. L. (1972), 'Teoria migracji', Przegląd Zagranicznej Literatury Geograficznej, 3/4, pp. 9-28.

FAST, V. K. (2011), Children's exodus: a history of the Kindertransport, London; New York: I.B. Tauris; New York: Palgrave Macmillan. https://doi.org/10.5040/9780755625604

GIGLIOTTI, S. and TEMPIAN, M. (2016), The young victims of the Nazi regime: migration, the Holocaust, and postwar displacement, London: Bloomsbury Academic. https://doi.org/10.5040/ 9781474219341

GOLDMAN, A. L. (1973), 'Defence Regulation 18B: Emergency Internment of Aliens and Political Dissenters in Great Britain During World War II', Journal of British Studies, 12 (2), pp. 120 136. https://doi.org/10.1086/385645

HAMMEL, A. and LEWKOWICZ, B. (2012), The kindertransport to Britain 1938/39: new perspectives, Amsterdam: Rodopi. https://doi.org/10.1163/9789401208864

HARRIS, J. M. and OPPENHEIMER, D. (2000), Into the arms of strangers: stories of the Kindertransport, London: Bloomsbury.

KAPP, Y. and MYNATT, M. (1997), British Policy and the Refugees 1933-1939, London: Frank Cass \& Co. LTD.

KUSHNER, T. (2017), Journey from the Abyss: the Holocaust and Forced Migration from the 1880s to the Present, Liverpool: Liverpool University Press. https://doi.org/10.2307/j.cttlps328t

KUSHNER, T. and CESARANI, D. (1993), The internment of aliens in twentieth century Britain, London; Portland, OR: F. Cass.

KUSHNER, T. and VALMAN, N. (1999), Remembering Cable Street: fascism and anti-fascism in British society, London: Vallentine Mitchell.

LASSNER, P. (2008), Anglo-Jewish women writing the Holocaust: displaced witnesses, Basingstoke: Palgrave Macmillan. https://doi.org/10.1057/9780230227361

LAQUEUR, W. (2001), The fate of young Jewish refugees from Nazi Germany, Hanover: University Press of New England. https://doi.org/10.26812/9781584651062

LEVERTON, B. and LOWENSOHN, S. (1990), I came alone, Lewes: The Book Guild Ltd.

MACAULAY, G. (1963), Travelyan, Historia Anglii, Warsaw: PWN.

MILTON, E. (2005), The tiger in the attic: memories of the Kindertransport and growing up English, Chicago: University of Chicago Press; Bristol: University Presses Marketing. https://doi. org/10.7208/chicago/9780226529486.001.0001

PULZER, P. (1992), Jews and the German State - The Political History of a Minority 1848-1933, Oxford: Blackwell.

RAVENSTEIN, E. G. (1976), The laws of migration, New York: Arno Press.

ROSNER, A. M. (2016), 'Kindertransporty - brytyjskie akcje ratowania żydowskich dzieci w latach 1938-1939', Zagłada Żydów. Studia i Materiały, 12, pp. 141-168. https://doi.org/10.32927/ ZZSiM.412

RUTHERFORD, A. (1936), 'Society for the Protection of Science and Learning', Nature, 158, 1 (3924), p. 607. https://doi.org/10.1136/bmj.1.3924.607

STOLZBERG KOROBKIN, F. (2008), Throw your feet over your shoulders: beyond the Kindertransport, New York; London: Devora Pub. 
TYDOR BAUMEL-SCHWARTZ, J. (2012), Never Look Back: The Jewish Refugee Children in Great Britain, 1938-1945 (Shofar Supplements in Jewish Studies), West Lafayette: Purdue University Press. https://doi.org/10.2307/j.ctt6wq5sw

\section{WEBSITES}

http://timewitnesses.org/english/IsleOfMan.html [accessed on: 28.01.2021] http://www.kindertransport.org/history.htm [accessed on: 28.01.2021] http://www.nature.com/nature/journal/v158/n4003/abs/158092c0.html [accessed on: 28.01.2021] https://encyclopedia.ushmm.org/content/en/article/kindertransport-1938-40 [accessed on: 28.01.2021] https://www.nature.com/articles/131793c0 [accessed on: 28.01.2021] https://www.unhcr.org/4ec262df9.pdf [accessed on: 28.01.2021] https://www.worldjewishrelief.org/about-us/kindertransport [accessed on: 28.01.2021] 